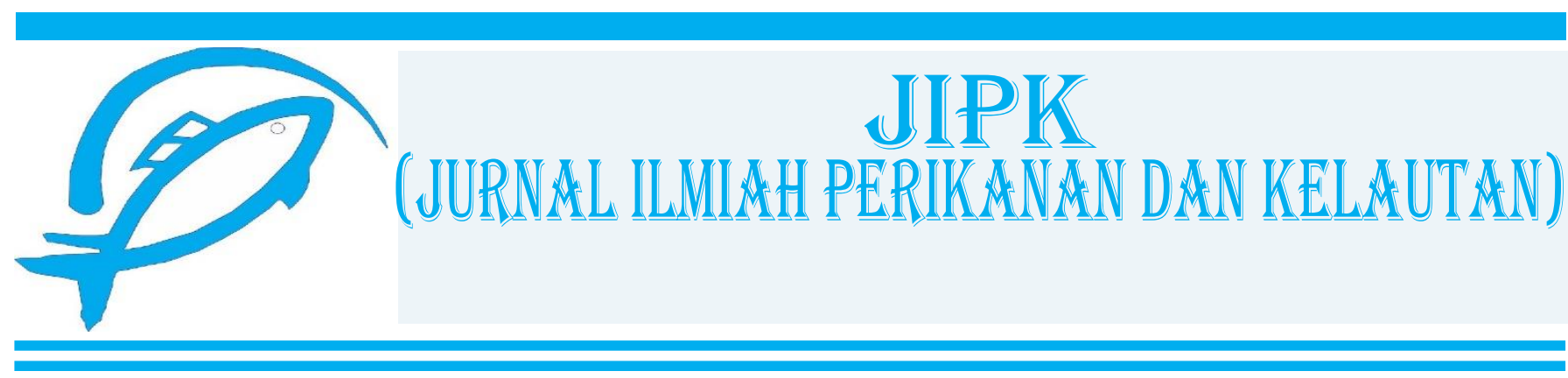

Research Article

\title{
Characteristics of Gipang, a traditional food of Baduy Tribe, Added with Milkfish Bone Flour to Improve Calcium and Phosphor Content
}

\author{
Baity Nur Jannah $^{1 *}$ (D), Fitria Riany Eris ${ }^{2}$, Nita Kuswardhani ${ }^{3}$ and Aris Munandar ${ }^{4}$
}

${ }^{1}$ The Study Program of Agricultural Product Technology, Faculty of Agriculture Technology,University of Jember, Indonesia

${ }^{2}$ The study program of Food Technology, Faculty of Agricultural, University of Sultan Ageng Tirtayasa, Indonesia

${ }^{3}$ The Study Program of Agricultural Industrial Technology, Faculty of Agriculture Technology, University of Jember,

Indonesia

${ }^{4}$ The Study Program of Fisheries, Faculty of Agricultural, University of Sultan Ageng Tirtayasa, Indonesia

\section{OPEN $\bigcirc$ ACCESS}

\section{ARTICLE INFO}

Received: January 02, 2020

Accepted: September 25, 2020

Published: September 27, 2020

*) Corresponding author:

E-mail: baitynurek@gmail.com

Keywords:

Baduy

Bone flour

Calcium

Gipang

Milkfish

This is an open access article under the CC BY-NC-ND license (http://creativecommons.org/licenses/by-nc-nd/4.0/)

\begin{abstract}
Gipang is a well-known traditional food of Baduy, a local tribe located in Banten Province, West Java, Indonesia. This study aimed at the characterization of the traditional food with an addition of milkfish bone flour at four different concentrations. The study used a completely randomized design (CRD) with a single factor (concentration of milkfish bone flour addition). The addition of milkfish bone flour consisted of four levels, which were $0 \%$ as the control, $5 \%, 10 \%$, and $15 \%$ of the weight of raw white glutinous rice used in the present study. Each treatment had 3 (three) replicates. During the experiment, the observed parameters were proximate analysis, calcium content, phosphorus content, hardness, total valuable count (TVC) of microbes, and organoleptic characteristics (colour, taste, scent, texture, overall). Fishbone flour is processed from milkfish bone waste that obtained from the milkfish satay industry in Banten province. The addition of milkfish bone flour had a significant effect on ash, protein, fat, calcium, and phosphor contents, hardness, total microbes, and organoleptic properties of colour, taste, and overall values. The result showed that the best concentration of milkfish bone flour addition to the Gipang was $10 \%$ which had content characteristic respectively as follows: moisture $6.74 \%$; ash $2.61 \%$; protein $5.71 \%$; fat $21.84 \%$; carbohydrate $63.10 \%$; calcium $3.68 \%$; and phosphor $1.39 \%$; hardness of $324.39 \mathrm{~g} / \mathrm{mm}$; TVC of microbes was 1.79 $\log 10 \mathrm{CFU} / \mathrm{ml}$; and organoleptic of colour 4.56; scent 4.40; taste 5.16; texture 5.08; and overall value of 5.28 .
\end{abstract}

Cite this as: Jannah, B. N., Eris, F. R., Kuswardhani, N., \& Munandar, A. (2020). Characteristics of Gipang, a traditional food of Baduy Tribe, Added with Milkfish Bone Flour to Improve Calcium and Phosphor Content. Jurnal Ilmiah Perikanan dan Kelautan, 12(2):276- 285. http://doi.org/10.20473/jipk.v12i2.17064. 


\section{Introduction}

Gipang is a traditional food of Baduy tribe, one of Indonesian tribe located at Banten Province, Indonesia. The food is cube shape with a sweet taste and made from sticky rice and sugar syrup. The abundance of sticky rice in the Baduy region makes Gipang as one of the most common products as well as become a favourite souvenir of the Baduy tribe and the Banten region. In general, Gipang is made from white glutinous rice with high carbohydrate content. The steamed glutinous rice contains $53.70 \mathrm{~g} / 100 \mathrm{~g}$ carbohydrates (Ministry of Health Republic of Indonesia, 2017). Gipang can be developed into high-value food by increasing the quality of its nutritional contents. Increased nutrient content of Gipang can be done by adding other food ingredients, one of which is fishbone flour which can increase the calcium and phosphorus contents.

Calcium and phosphorus are important minerals required by our body. According to Bredbenner et al. (2007), calcium plays an important role in the process of bone and tooth formations. Calcium deficiency during growing stage may cause growth disorders such as weak bone (hypocalcemia), easy to bend and brittle or in adults is usually called osteoporosis (Almatsier, 2006). While, phosphorus plays a critical role in the process of muscle contraction, in bone formation (ossification) and secretory activity (Piliang and Djojosoebagio, 2006).

Fishbone meal is one of the food products which can use fishbone waste as its basic ingredients. Fishbones contain living cells and intracellular matrix in the form of mineral salts consisting mainly of calcium and phosphate as much as $80 \%$, while the rest consists of calcium carbonate and magnesium phosphate $100 \mathrm{~cm} 3$ per $10,000 \mathrm{mg}$ of bone containing calcium (Sa'adah, 2013).

One of the fishbone meal sources is milkfish bones. In Banten Province, milkfish is processed into Banten's special food, namely milkfish satay with side product of milkfish bone. The milkfish bone waste can be used as a source of calcium and phosphorus. According to Salitus et al. (2017), milkfish bone meal contains $35.22 \%$ protein; $9.68 \%$ calcium, $30.47 \%$ ash, and $23.06 \%$ fat. According to Bakhtiar et al. (2019), at 2.9 grams of milkfish bone meal containing $5.24 \%$ calcium and $2.36 \%$ phosphorus.

The addition of milkfish bone flour to Gipang can increase calcium and phosphorus content in the traditional food. However, the addition of the fishbone flour may also change the characteristics of Gipang. Thus, the present study aimed at investigating the effect of milkfish bone flour addition on characteristics of
Gipang and find out the best concentration to give the most preference for consumers.

\section{Materials and Methods}

\subsection{Materials}

Equipment to prepare the milkfish bone flour and Gipang were blenders, ovens, sieves, wooden spatulas, pans, stoves, Gipang molds, rolling pin, rheotex, an analytical balance, weighing bottles, ovens, excitatory, porcelain cups, incinerators, buchi K-355, soxhlet, water bath, blue tips, micropipet, autoclave, incubator, colony counter, incinerators and appliances glassware. While materials used in the present study were white glutinous rice, white crystal sugar and tamarind fruit obtained at the market in Serang city and milkfish bones obtained from the milkfish satay industry in Serang city.

\subsection{Experimental design}

This research was conducted using a completely randomized design (CRD) with a single factor which was the concentration of milkfish bone flour. There were four treatments, which were a different dose of fishmeal bone flour $(0 \%, 5 \%, 10 \%$ and $15 \%$ of the weight of raw white glutinous rice) with three replicates of each.

\subsection{Preparation of milkfish bone flour}

The preparation of milkfish bone flour was performed according to a modified protocol of Darmawangsyah (2016). In brief, the milkfish bone was boiled for one hour at $80 \pm 1^{\circ} \mathrm{C}$. Thereafter, the boiled fishbone was washed and boiled again for 1 hour at the same temperature. Afterwards, it was softened with presto pan for 1 hour at $121{ }^{\circ} \mathrm{C}$. Furthermore, the fishbone was dried using an oven for 9 hours at a temperature of $50^{\circ} \mathrm{C}$. The dried fishbone was pulverized using a blender and then sieved using a 20 mesh sieve to obtain homogenate milkfish bone flour.

\subsection{Gipang Production}

Production of the food (Gipang) was divided into three stages in general including (1) preparation of sticky rice, (2) preparation of sugar syrup and (3) producing Gipang. The main ingredients were glutinous rice; $50 \%$ white crystalline sugar; $12.5 \%$ acidic fruit; $20 \%$ water; and milkfish bone flour $(0 \%, 5 \%, 10 \%$ or $15 \%)$ by weight of raw white glutinous rice. The procedure of Gipang production is presented in Figure 1.

\subsection{Observed parameters}

Parameters which were observed in the present consisted of chemical properties, physical appearances, total microbial count, organoleptic characteristics, and effectiveness tests. Chemical analysis was performed by measuring moisture content, ash content, crude protein content, crude fat content and carbohydrate content 
according to the protocol of AOAC (2005). Besides, calcium and phosphorus levels in the Gipang were measured according to a protocol of Sudarmadji et al. (1997).
The results of chemical measurement, physical appearances and microbiological assays were analyzed statistically using analysis of variance (ANOVA), and

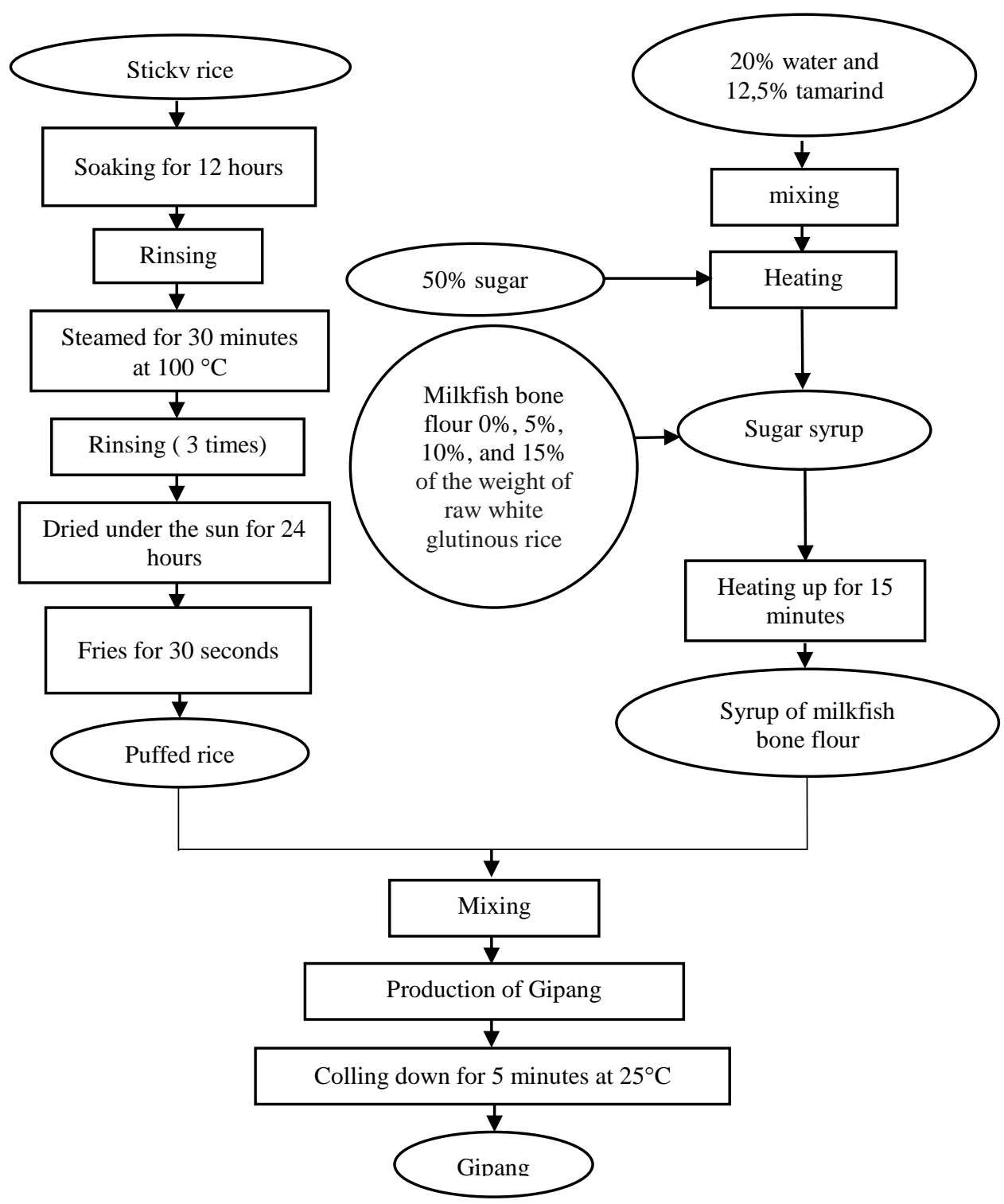

Figure 1. Production of Gipang: procedures and steps with the addition of milkfish bone flour source: modified procedure of Rahardja (2016).

Physical appearance analysis in the form of the value of violence using rheotex. Analysis of total microbial count was done by measuring Total Plate Count using spreading culture method. Organoleptic characteristics such as colour, aroma, texture, taste, and overall preference were tested using a seven scale hedonic test. In the end, the determination of the best treatment was analyzed using the effectiveness test method of De Garmo et al. (1984).

\subsection{Data Analysis}

Followed by Duncan's Multiple Range Test (DMRT) if there was a significant difference between treatments at $\alpha \leq 5 \%$. While sensory analysis results were processed using the Kruskal-Wallis method and followed by the Mann Whitney test if there was a significantly difference among treatments at $\alpha \leq 5 \%$.

\section{Result and Discussion}

\subsection{Chemical composition Moisture content}

Moisture content in Gipang ranged from 6.10 to $6.84 \%$, Figure 2. The highest moisture content appeared to be found in Gipang with the addition of $15 \%$ milkfish bone flour. However, the values of moisture content among treatments based on ANOVA test 
results were statistically no significantly different. $\mathrm{P}>0.05$. The moisture content might be influenced by the basic ingredients used in the present study. This result could be due to the low moisture content in the milkfish bone flour and the range of the addition of milkfish bone flour was very close, which was 5\% between treatments. According to Salitus et al. (2017), milkfish bone meal only contained a moisture content of $5.44 \%$.

\section{Ash Content}

According to Sudarmadji (1997), the ash content in a product was closely related to the mineral content in an ingredient, the purity, and cleanliness of a material produced. Ash contents in the Gipang with the addition of milkfish bone meal were found to be $0.40-4.56 \%$, Figure 3 .
The highest ash content was obtained from Gipang with the addition of $15 \%$ fishbone flour. Furthermore, ANOVA test results showed that the addition of fishbone meal significantly affected the ash our was added, the higher the ash content of the traditional food. The high ash content in the food might be due to the addition of milkfish bone meal. High ash content in fishbone flour was previously reported by Putranto et al. (2015) in which the main components of bone are minerals. Bones had living cells and intracellular matrix in the form of mineral salts. The mineral salt is a component that consists of calcium phosphate as much as $80 \%$ and the rest consists of calcium carbonate and magnesium phosphate so that this element makes the ash content in pastry products increase (Tababaka, 2004).

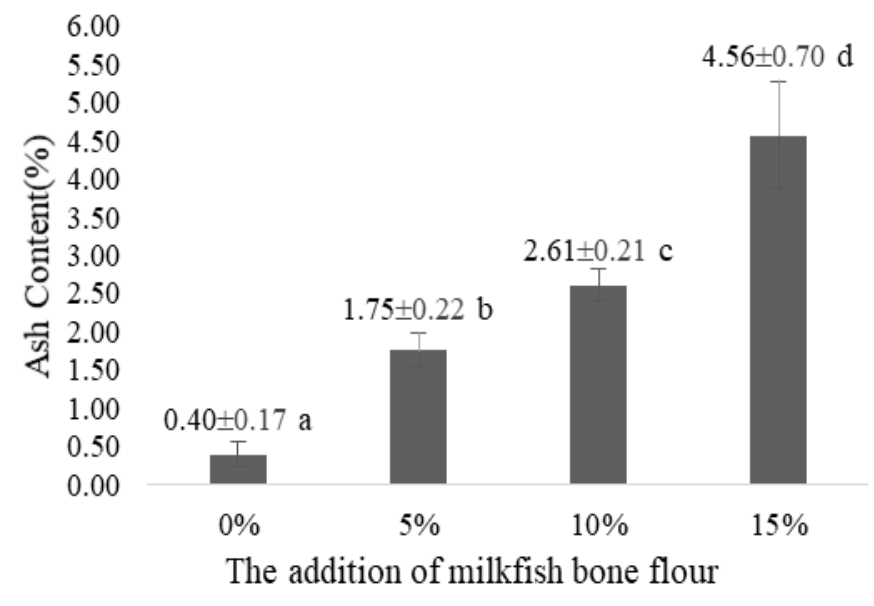

Figure. 2) Moisture content in Gipang (a traditional food of Baduy Tribe) with the addition of milkfish bone flour at four different concentrations. 3) Ash content of Gipang with the addition of milkfish bone flour at four different concentrations.
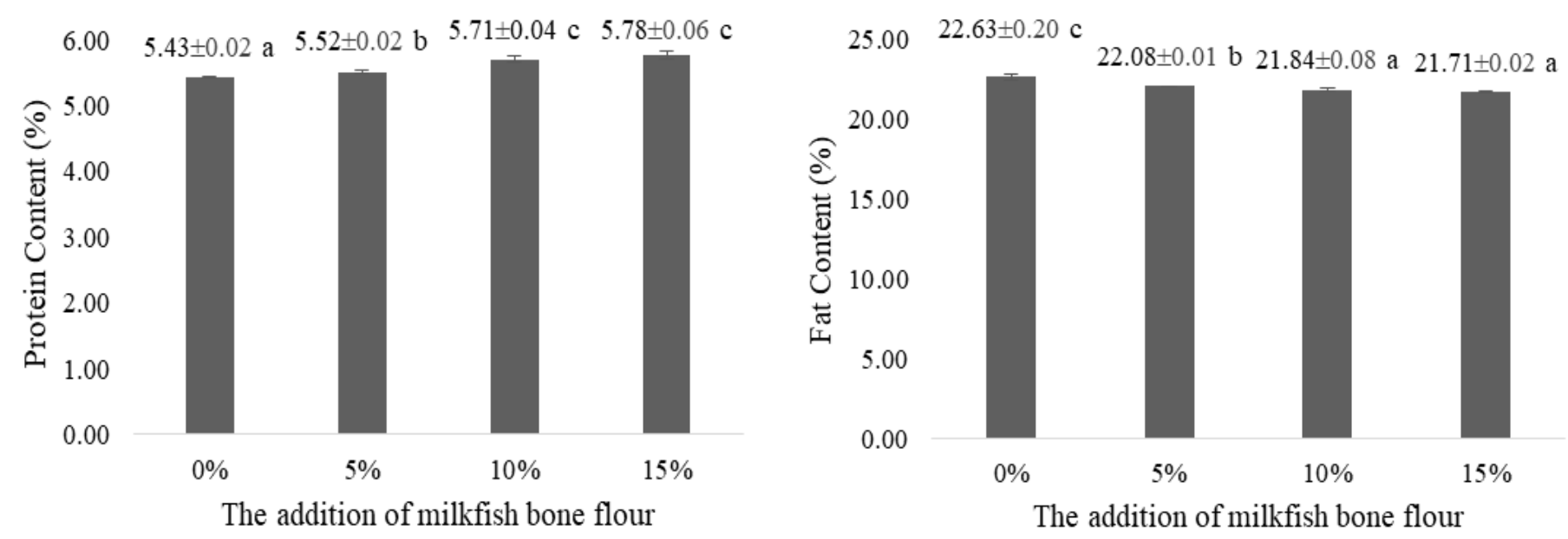

Figure. 4) Crude protein content of Gipang with the addition of milkfish bone flour at four different concentrations .5) Crude fat content of Gipang with the addition of milkfish bone flour at four different concentrations. 
ANOVA test result showed that the addition of milkfish bone meal significantly affected the levels of CP content in Gipang $\mathrm{p}<0.05$. The CP of Gipang with the addition of $15 \%$ milkfish bone meal was significantly different from Gipang with the addition of $0 \%$ and $5 \%$ but did not significantly different from $\mathrm{CP}$ in Gipang with the addition of $10 \%$ milkfish bone flour. In general, the higher addition of bone flour, the higher protein levels in Gipang. According to Salitus et al. (2017), milkfish bone meal contained $35.22 \%$ protein. Thus the high protein content of milkfish bone flour causes increasing the protein content of Gipang.

\section{Crude Fat}

The crude fat content of Gipang in all treatments

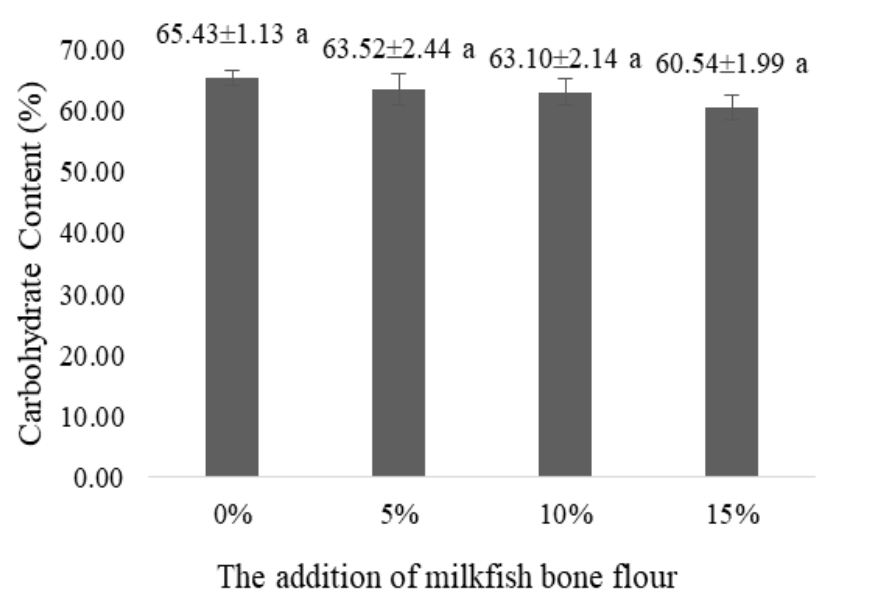

ranged from 21.71 to $22.63 \%$, Figure 5 . The highest crude fat content was obtained from Gipang without the addition of milkfish bone meal, 22.63\%. ANOVA test results showed that the addition of milkfish bone meal significantly affected Gipang fat content. The addition of milkfish bone flour by $15 \%$ is not significantly different from the addition of $10 \%$, but it gives a significantly different addition of milkfish bone flour $0 \%$ and $5 \%$. The higher the concentration of the addition of milkfish bone meal, the lower the crude fat content. Loss of fat content can occur due to denaturation of protein in tissues to a degree that can cause a significant decrease in the emulsification characteristic of protein (Pratama et al., 2014). According to Windsor (2001), the protein will coagulate if the material is heated so that a lot of fat will come out.

Figure. 6) Carbohydrate content of Gipang with the addition of milkfish bone flour at four different concentrations.

7) Calcium content of Gipang with the addition of milkfish bone flour at four different concentrations.
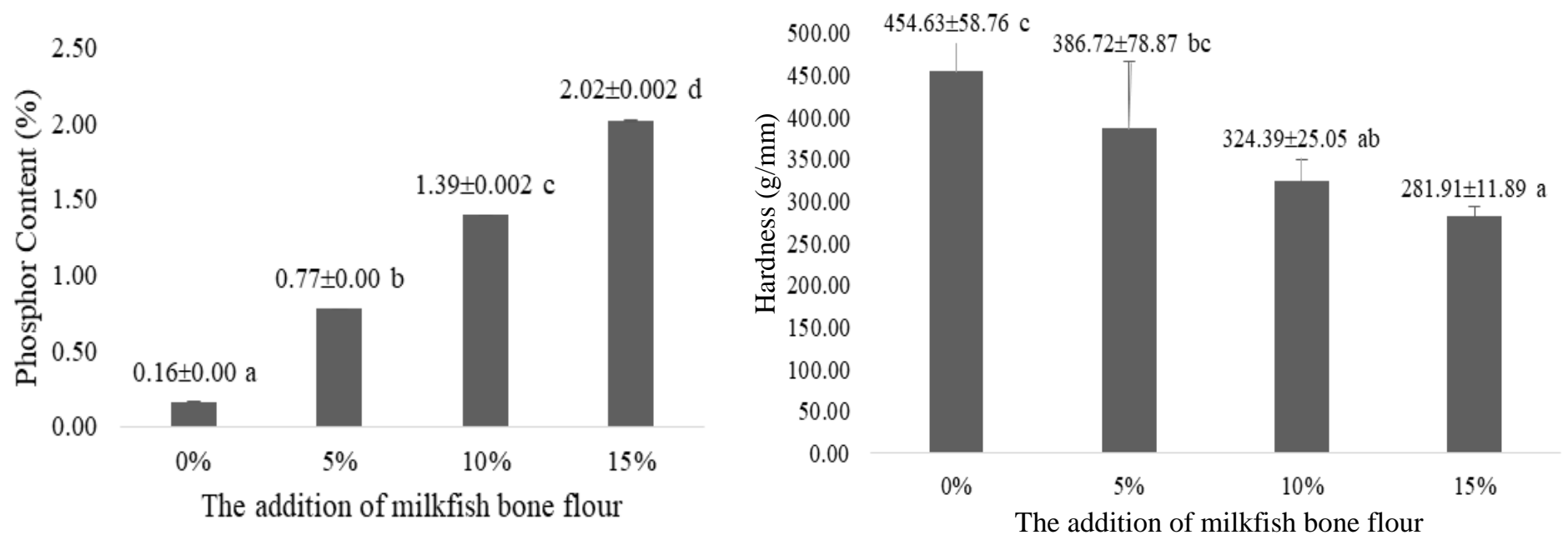

Figure. 8) Phosphor content of Gipang with the addition of milkfish bone flour at four different concentrations.

9) The hardness value of Gipang with the addition of milkfish bone flour at four different concentrations. 
Therefore, the increase of milkfish bone meal concentration leads to an increase in the protein content of Gipang. The higher the protein content, the more denatured protein will affect the protein emulsification properties. The denatured protein decreases its attachment to crude fat so that more crude fat content comes out of the material.

\section{Carbohydrate content}

The result showed in general that the higher the concentration of milkfish bone flour addition, the lower the carbohydrate content in the Gipang. Carbohydrate levels observed in the present study ranged from $60.54 \%$ to $65.43 \%$, Figure 6 . The highest level of carbohydrate was found in Gipang without the addition of milkfish bone meal with an average value of $65.43 \%$. ANOVA test results showed that the addition of milkfish bone meal did not significantly affect the levels of carbohydrate of Gipang. Low levels of carbohydrates in milkfish bone flour because the addition has no effect on carbohydrate levels in Gipang. According to Salitus et al. (2017), milkfish bone meal only has a carbohydrate content of $5.81 \%$. Kaya (2008) states that fish bone meal contain more minerals, especially calcium and phosphorus and have low carbohydrate content.

\section{Calcium Content}

The calcium levels in the Gipang were measured at 0.01 to $5.61 \%$, Figure 7 . The highest level of calcium content was found in the Gipang with the addition of $15 \%$ milkfish bone meal, with an average value of $5.61 \%$. ANOVA test results showed that the addition of milkfish bone meal significantly affected the calcium content of Gipang. The higher the concentration of the addition of milkfish bone meal, the higher the calcium content in the Gipang. That is because milkfish bones contain high calcium. According to Salitus et al. (2017), milkfish bone flour contained $9.68 \%$ calcium. Thus, the higher the concentration of the addition of milkfish bone flours to crackers, the higher the calcium content.
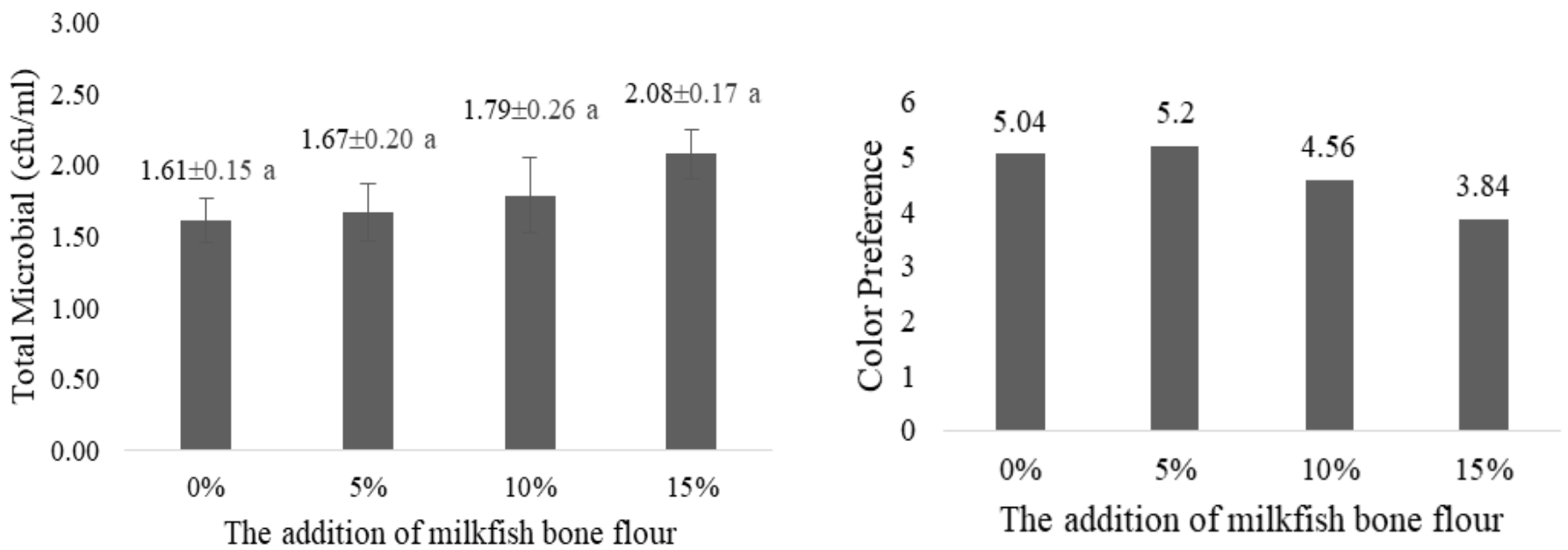

Figure. 10). Total microbial count of Gipang with the addition of milkfish bone flour at four different concentrations. 11) Colour preference values of Gipang with the addition of milkfish bone flour at four different concentrations.

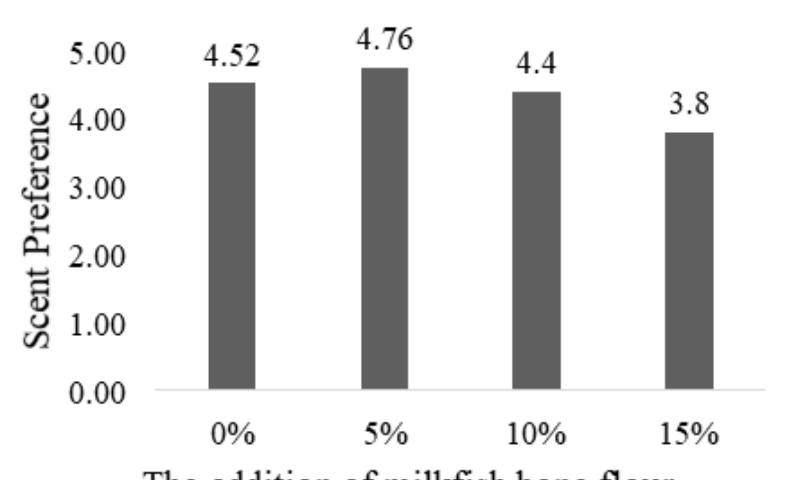

The addition of milkfish bone flour

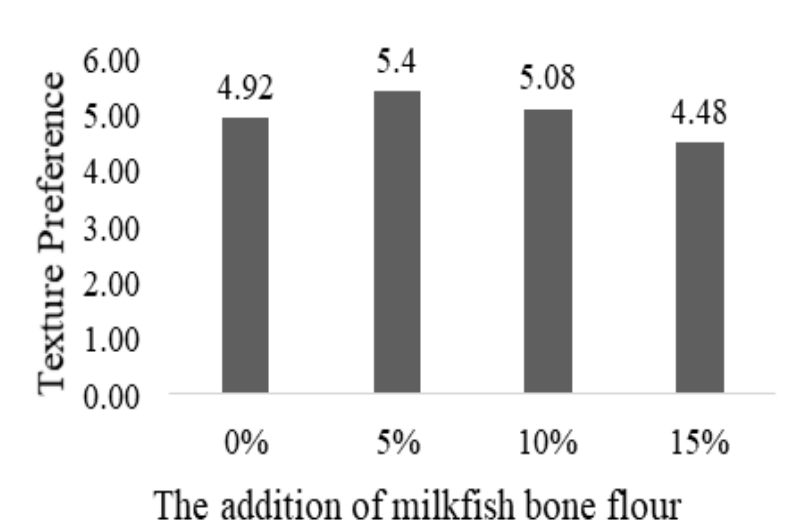

The addition of milkfish bone flour

Figure.12) Scent preference of Gipang with the addition of milkfish bone flour at four different concentrations.13) Texture preference of Gipang with the addition of milkfish bone flour at four different concentrations. 


\section{Phosphor Content}

Chemical analysis showed that the phosphorus content in the Gipang was $0.61-2.02 \%$, Figure 8. The highest level of phosphorus was found in the Gipang with the addition of $15 \%$ milkfish bone meal, an average value of $2.02 \%$. ANOVA test results showed the addition of fishbone meal significantly affected Gipang phosphorus levels. The difference in concentration of addition of fishbone meal leads to different phosphorus levels of Gipang. The higher the addition of milkfish bone flour concentration to the Gipang, the higher the value of the phosphorus content. This could be due to a milkfish bone meal contains a high level of phosphorus. Bakhtiar et al. (2019) viewed that at 2.9 grams of milkfish, the bone meal contains $2.36 \%$ phosphorus Fishbone meal contains nano calcium and calcium-phosphorus which have the highest availability among other calcium (Lestari, 2001).

\subsection{Hardness}

The hardness of Gipang with an additional fishbone flour ranged from 281.9 to $454.63 \mathrm{~g} / \mathrm{mm}$, Figure 9. The highest hardness value was found in the Gipang without the addition of milkfish bone flour. While the lowest hardness value was found in the Gipang with the $15 \%$ addition of milkfish bone meal. ANOVA test results showed that the addition of milkfish bone meal on the Gipang significantly affected Gipang hardness. The hardness of Gipang with the $15 \%$ milkfish bone meal was significantly different from the addition of $0 \%$ or $5 \%$, but not significantly different from the addition of $10 \%$. The addition of $10 \%$ of milkfish bone flour was not significantly different from the addition of $5 \%$ and the addition of $5 \%$ of milkfish bone flour was not significantly different from the addition of $0 \%$. In general, the more concentration of milkfish bone flour used in the ingredients, the less value of hardness.

The lower hardness value, the crunchier the texture would be. The decrease in the value of hardness is due to the higher content of Gipang ash with increasing concentration of the addition of milkfish bone meal. Bernard (1989) stated that high ash content in sucrose will cause an increase in inversion, staining and triggering the formation of foam during the process of heating the sugar solution. Thereby increasing the air bubbles trapped in the sugar period. Excessive use of sugar can cause the food product to become sticky and cannot harden.

\subsection{Total Microbial Count}

The total microbial count in the Gipang with milkfish flour addition ranged from $1.61 \operatorname{logs} \mathrm{CFU} / \mathrm{g}$ to $2.08 \operatorname{logs} \mathrm{CFU} / \mathrm{g}$, Figure 10. The lowest total number of microbes was observed from Gipang without the addition of milkfish bone meal. While the highest total microbial count was counted from Gipang with the addition of $15 \%$ milkfish bone flour with an average value of
$2.08 \log \mathrm{CFU} / \mathrm{g}$. However, statistical analysis using ANOVA indicated that the addition of fishbone meal did not significantly affect the total microbes in Gipang, $p>0.05$. Though, a general pattern suggests that the more addition of milkfish bone meal, the more microbial count in the Gipang. The result might be related to a high nitrogen compound in the fishbone flour and become a good growth medium for microbial growth. According to Widiani (2008), microorganisms in food will degrade macromolecules (protein, carbohydrates and fats) into organic compounds. The breakdown of carbohydrates by microbes can produce organic acids (lactic acid, acetic acid, butyric acid and propionate acid), neutral products (acetone, butyl alcohol and ethyl alcohol) and gases (methane, hydrogen and carbon dioxide).

\subsection{Organoleptic assays}

\section{Colour}

Based on its colour appearance, Gipang with the addition of different concentration of fishbone flour was given average scores from 3.84 to 5.2, Figure 11. The best colour appearance was obtained from Gipang with the addition of $5 \%$ milkfish bone flour, an average value of 5.2. Further statistical analysis using the KruskalWallis calculation showed that the addition of milkfish bone meal has a significant effect on Gipang colour preferences. The addition of milkfish bone flour at 5\% and $10 \%$ was not significantly different from the control (without the addition of milkfish bone flour; 0\%), but it was significantly different from the addition of $15 \%$. The more milkfish bone flour added to the Gipang, the level of panelists' preference for the colour of the Gipang decreased. The addition of milkfish bone flour turned the Gipang colour into brown. This result could be due to the colour of milkfish bone flour (brownish) which can be caused by a non-enzymatic browning reaction during drying. According to Buckle et al. (2010), drying produced a dark coloured material because the product charred due to browning reactions which occurred non enzymatically.

\section{Scent}

The results showed the scent preference value given by the panelists ranged from 3.8 to 4.76 , Figure

12. The most preferred scent was obtained from Gipang with the addition of 5\% milkfish bone meal, with an average value of 4.76. Statistical analysis by using Kruskal Wallis indicated that the addition of milkfish bone meal has no significantly effect on the scent of the Gipang. The higher milkfish bone flour which was added to the ingredients, the less preference of scent value was obtained. The scent of fishbone flour appeared to be quite difficult to remove and tends to mask the distinctive scent of other ingredients (Maulida, 2005). Darmawangsyah (2016) described that milkfish had a distinctive scent that smells of mud and soil attached to the bone meal of milkfish. 


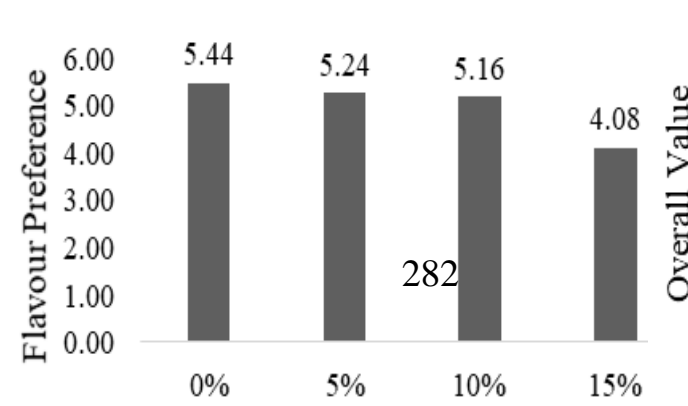

The addition of milkfish bone flour

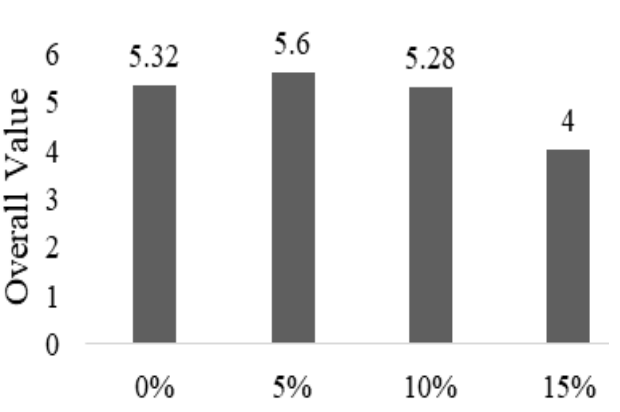

The addition of milkfish bone flour

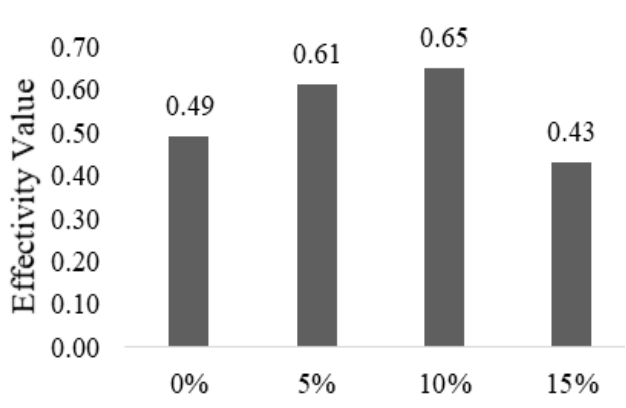

The addition of milkfish bone flour

Figure. 14) Flavour preference values of Gipang with the addition of milkfish bone flour at four different con- centr. 15) Overall value of Gipang, with the addition of milkfish bone flour at four different concentrations. 16) Effectivity values of Gipang with the addition of milkfish bone flour at four different concentrations.

\section{Texture}

Texture preference of Gipang was valued from 4.48 to 5.4 , Figure 13 . The best texture was found in the Gipang with the addition of 5\% milkfish bone flour, an average value of 5.4. The Kruskal Wallis assay showed that the addition of milkfish bone meal did not significantly affected the preference of the Gipang texture. The addition of milkfish bone flour with interval only $5 \%$ was considered to have no significant effect on the texture of Gipang.

\section{Flavour}

The flavour preference values of Gipang with the addition of fishbone flour were scored at 4.08 to 5.44, Figure 14. The most preferred flavour was obtained from Gipang with no addition of milkfish bone flour, an average value of 5.44. Kruskal Wallis test results showed that the addition of milkfish bone meal significantly affected the taste of Gipang. The flavour values of Gipang at the addition of $0 \%, 5 \%$ and $10 \%$ of milkfish bone flour were not significantly different, but the values of the three treatments were significantly different from Gipang with the addition of $15 \%$ fishbone flour. The higher concentration of milkfish bone flour addition, the lower value of Gipang flavour. This could be because of the taste of fishbone flour become very dominant at the end product. According to Kaya (2008), high calcium and phosphorus content in catfish bone meal results in a slightly chalky taste. Similarly, Apriyana (2014) reported that a high addition of catfish bone flour to Cilok, meatball, results in savory taste. The difference in flavour between milkfish bone flour and Gipang causes the taste preference value decrease.

\section{Overall}

Overall, the preference value of Gipang with the addition of milkfish bone flour ranged from 4.0 to
5.6, Figure 15. The highest overall preference value was obtained from Gipang with the addition of $5 \%$ milkfish bone flour, an average value of 5.6. The Kruskal Wallis test results showed that the addition of milkfish bone flour significantly affected the overall preference level of Gipang, $\mathrm{p}<0.05$. Overall preference values of Gipang with the addition of $0 \%, 5 \%$ and $10 \%$ were not significantly different, but those treatments had significantly different from Gipang with the addition of $15 \%$. The overall fondness for Gipang by the addition of milkfish bone flour is influenced by the colour, texture, scent and taste preferences. The highest overall preference value is found in Gipang with the addition of 5\% milkfish bone meal. The results are in accordance with the highest preference value for the parameters of colour, scent and texture preferences, with the addition of $5 \%$.

\subsection{Effectiveness Assay}

The effectiveness assay was performed to determine the best treatment based on several parameters. The parameters used for effectiveness assay included organoleptic analysis which included colour, taste, scent and texture, chemical analysis results which include calcium, phosphorus, ash, carbohydrates, crude fat, crude protein, and moisture and total microbial count. The results of the effectiveness as seen in Figure 16 showed that the effectiveness test values ranged from 0.43 to $0.65 \%$. The best value of the effectiveness test results are in the Gipang with the addition of $10 \%$ milkfish bone meal with content a moisture $6.74 \%$; ash $2.61 \%$; crude protein $5.71 \%$; crude fat $21.84 \%$; carbohydrate $63.10 \%$; calcium $3.68 \%$; and phosphorus $1.39 \%$; hardness of $324.39 \mathrm{~g} / \mathrm{mm}$; total microbial count of $1.79 \log \mathrm{CFU} / \mathrm{g}$; colour preference 4.56 (like); 4.40 favorite scent (neutral); taste preferences 5.16 (like); texture preference 5.08 (like); and overall fondness 5.28 (like). 


\section{Conclusion}

The addition of milkfish bone flour to the Gipang significantly affected ash, crude protein, crude fat, calcium, and phosphorus contents, hardness, total microbial count, colour, preference, taste and overall. However, the treatments did not significantly affected moisture, and carbohydrate contents, preference scent and texture. The result also showed that the best concentration of milkfish bone flour addition was $10 \%$ of glutonized rice.

\section{Acknowledgment}

The authors would like to express gratitude to Faculty of Agricultural Technology, Universitas Jember and Faculty of Agricultural Technology, Universitas Sultan Ageng Tirtayasa as a research site, IsDB Universitas Jember and IsDB University of Sultan Ageng Tirtayasa for the financial support, and also to all members for supporting this research.

\section{Author's Contributions}

1. Baity Nur Jannah: carried out the experiment, collected the data, wrote the manuscript with support first and second author

2. Fitria Riany Eris: conceived of the presented idea; designed, performed, and supervised the experiments, discussed the results and contributed to the final manuscript

3. Nita Kuswardhani: verified the teoritycal and analytical methods, and discussed the results and contributed to the final manuscript

4. Aris Munandar: helped supervise the project

\section{Conflict of Interest}

The authors declare that they have no competing interests.

\section{Funding Information}

This Research Project was fully sponsored by Islamic Development Bank (IsDB) through funding from University of Sultan Ageng Tirtayasa Research Grant 2018 and IsDB University of Jember with grant number IDN 1008.

\section{References}

Almatsier, S. (2006). Prinsip dasar ilmu gizi. Jakarta : Gramedia.

AOAC. (2005). Official methods of analysis of the association of analytical chemists. Washington DC: AOAC Inc.

Apriyana, I. (2014). Pengaruh penambahan tepung kepala ikan lele (Clarias $s p$ ) dalam pembuatan cilok terhadap kadar protein dan sifat organoleptiknya. Unnes Journal of Public Health, 3(2): 1-9.

Bakhtiar, S., Rohaya, \& Ayunda, H. M. (2019). Penambahan tepung tulang ikan bandeng (Chanos chanos) sebagai sumber kalsium dan fosfor pada pembuatan donat panggang. Jurnal Teknologi dan Industri Pertanian Indonesia, 11(1): 38-45.

Bernard, W. M. (1989). Chocolate, cocoa, and confectionery science and technology. 3rd Ed. New York: The AV1 Pub.

Bredbenner, C. B., Beshgetoor, D., Moe, G., \& Berning, J. (2007). Wardlaw's perspective in nutrition. $8^{\text {th }}$ Ed. New York: McGraw \& Hill.

Buckle, K. A., Edwards, R. A., Fleet, G. H., \& Wootton, M. (2010). Ilmu pangan. Jakarta: UI Press. Darmawangsyah, Jamaluddin, P., \& Kadirman. (2016). Fortifikasi tepung tulang ikan bandeng (Chanos chanos) dalam pembuatan kue kering. Jurnal Pendidikan Teknologi Pertanian, 2: 149-156.

De Garmo, E. D., Sullivan, M. G., d \& Canada, J. R. (1984). Engineering Economy. New York: Mc. Millan Publishing Company.

Kaya, A. O. W. (2008). Pemanfaatan Tepung Tulang Ikan Patin (Pangasius sp) Sebagai Sumber Kalsium dan Fosfor dalam Pembuatan Biskuit. Skripsi. Bogor: Institut Pertanian Bogor.

Lestari, S. (2001). Pemanfaatan limbah tulang ikan tuna menjadi tepung. Bogor: Fakultas Ilmu Perikanan dan Kelautan Institut Pertanian Bogor.

Maulida, N. (2005). Pemamfaatan Tepung tulang ikan madidihang sebagai suplemen dalam pembuatan biskuit (crackers). Skripsi. Fakultas Perikanan dan Ilmu Kelautan, IPB. Bogor.

Ministry of Health Republic of Indonesia. (2017). DKBM (Daftar Komposisi Bahan Makanan). Jakarta: Departement of Health Republic of Indonesia.

Piliang, W. G. \& Djojosoebagio. (2006). Fisiologi nutrisi. Vol. II. Bogor: IPB Press. 
Pratama, R. I., Rostini, I., \& Liviawaty, E. (2014). Karakteristik biskuit dengan penambahan tepung tulang ikan jangilus (Istiophorus sp.). Jurnal Akuatika, (1): 30-39.

Putranto, H. F. , Asikin, A. N., \& Kusumaningrum, I. (2015). Karakterisasi tepung tulang ikan belida (Chitala sp.) sebagai sumber kalsium dengan metode hidrolisis protein. Ziraa'ah, 40(1): 1120.

Rahardja, A. (2016). Pengaruh proporsi sirup glukosa dan gula semut terhadap sifat fisikokimia dan organoleptik bipang beras hitam. Skripsi. Surabaya: Universitas Katolik Widya Mandala.

Sa'adah, U. (2013). Daya terima dan komposisi proksimat tepung tulang ikan lele yang Mengalami Proses Perendaman dalam Larutan Jeruk Nipis. Skripsi. Surakarta: Fakultas Ilmu Kesehatan Universitas Muhammadiyah Surakarta.

Salitus, Ilminingtyas, D.W.H., \& Fatarina, E.P. (2017).
Penambahan tepung tulang bandeng (Chanos Chanos) dalam pembuatan kerupuk sebagai hasil samping industri bandeng cabut duri. Serat Acitya Jurnal Ilmiah UNTAG Semarang, 6(2): 81-92.

Sudarmadji, S., Bambang, H., \& Suhardi. (1997). Analisis bahan makanan dan pertanian. Yogyakarta: Liberty.

Tababaka, R. (2004). Pemanfaatan tepung tulang ikan patin (Pangasius sp) sebagai bahan tambahan kerupuk. Skripsi. Bogor: Institut Pertanian Bogor.

Widiani, L. P. A. (2008). Ekstraksi, karakterisasi dan aplikasi garam alginate sebagai penstabil pada minuman sari buah belimbing (Averrhoa carambola L.). Skripsi. Bogor: Fakultas Perikanan dan Ilmu Kelautan, Institut Pertanian Bogor.

Windsor, M. L. (2001). Fish meat. United Kingdom: Torry Research. 